\title{
Evaluation of Teaching on Leprosy by Students at a Brazilian Public Medical School
}

\section{Avaliação do Ensino de Hansenologia pelos Estudantes de uma Escola Médica, Pública, Brasileira}

Cynthia Rossetti Portela Alves Marcelo Grossi Araújol Maria Mônica Freitas Ribeiro ${ }^{I}$ Elza Machado Melo

\section{KEYWORDS \\ - Teaching on Leprosy; \\ - Medical Students; \\ - Medical Education.}

\section{PALAVRAS-CHAVE}

- Hanseníase, Ensino.

- Estudantes de Medicina.

- Educação Médica.

Recebido em: 11/03/2015

Aprovado em: 04/04/2016

\begin{abstract}
Objectives: To evaluate teaching on leprosy at a public medical school located in a metropolis in southeastern Brazil with a low leprosy prevalence rate. Results: An analysis performed by means of a comparative cross-sectional study on two parallel groups of students (freshmen and interns) demonstrated that most students began the medical course with some knowledge of the signs and symptoms of the disease. The interns were shown to have more theoretical knowledge and more favorable attitudes toward the disease compared to the freshmen. Most of the interns stated that the topic had been addressed during the course but that practical teaching was insufficient. Students who had had the opportunity for practical experience with patients were more confident in their ability to attend to similar cases. Conclusion: Although from a statistical point of view the results may seem very favorable, the same cannot be said when assessing the situation from the perspective of education and public health, since a large number of final-year medical students have not been provided with basic information on the disease.
\end{abstract}

\section{RESUMO}

Objetivo: Avaliar o ensino sobre hanseníase numa escola médica localizada em metrópole do Sudeste brasileiro com baixo coeficiente de prevalência para hanseníase. Resultados: Em análise realizada, utilizando um estudo comparativo entre dois grupos paralelos de estudantes do curso médico (ingressantes e internos), observou-se que a maioria dos estudantes ingressa no curso com conhecimentos sobre sinais e sintomas da doença. Os internos mostraram maior conhecimento teórico, assim como atitudes mais favoráveis em relação à doença, quando comparados aos ingressantes. A maioria dos internos afirmou que o tema foi abordado durante o curso médico, mas que o ensino prático foi insuficiente. Estudantes que tiveram experiência prática mostraram maior confiança em sua habilidade para atender casos semelhantes. Conclusão: Embora do ponto de vista estatístico os resultados possam parecer favoráveis, não se pode afirmar o mesmo sob a perspectiva da educação e da saúde pública, uma vez que grande número de estudantes do último ano não possui informações básicas a respeito da doença. 


\section{INTRODUCTION}

There are different regional situations regarding the distribution of leprosy in Brazil, with areas of high endemicity and others with low prevalence and new case-detection rates. The decentralization of assistance, which is now offered at the primary health care level, was an important landmark for the increase in new case detection and large-scale MDT implementation, with the consequent reduction in treatment duration and disease prevalence. ${ }^{1,2}$

Maintaining the interest of health professionals in neglected diseases, including leprosy, when facing a complex prevalent nosology, which includes an increase in both chronic degenerative diseases and externally caused events, ${ }^{3}$ has become a challenge for health services at all levels. The challenge is even greater in low-prevalence areas, where the diagnosis of new cases, though less frequent, still exists and should continue for years or even decades. ${ }^{4,5}$

Leprosy control is based on early diagnosis and adequate, timely treatment. The training of human resources, from undergraduate courses in the health area to continuing education, plays a fundamental role. However, the small number of cases observed in basic health units in low-prevalence areas makes it difficult to maintain expertise and to train new human resources. ${ }^{6}$

Indeed, how to teach about leprosy in scenarios marked by great disparities in the epidemiological situation of the disease has caused worldwide restlessness and discussions. ${ }^{6-10}$

The objective of the present study was to evaluate leprosy instruction in a large, public medical school located in a metropolis of southeastern Brazil with low leprosy prevalence rates.

\section{MATERIALS AND METHODS}

The study was carried out at the Medical School of the Federal University of Minas Gerais (FM/UFMG), which is located in the city of Belo Horizonte. The student body consists of approximately 1920 students divided into 12 one-semester periods, with an average of 160 students per period. The Medicine course starts with a basic cycle during the first four periods, with essentially biological and theoretical content. Following this, there is a professional cycle divided into ambulatory practice and internships. In this phase, the student begins patient clinical assessment in the presence of a teacher who supervises the student and has legal responsibility for the medical procedure. Initially, this occurs in basic outpatient units, which includes attending patients in public health services with no direct connection to the teaching hospital; the outpatient clinic is the main practice site during most of the course. In the last three periods, clinical and surgical internships are undertaken in teaching hospitals. The internship in public health is carried out in small towns and rural communities and includes public health activities and patient assistance.

Six hundred and thirty-two students in the first and in the last year of the Medicine course in 2012 were included in this study. A comparative cross-sectional design between two parallel groups was implemented: Group 1 (freshmen, first year), when the student's knowledge is similar to that of the general population; and Group 2 (interns, last year), when most of the theoretical and practical content has already been addressed.

A structured self-administered form with 16 closed questions and 3 open questions was used for Group 1; 21 closed questions and 6 open questions was used for Group 2. The questionnaire was developed by the researchers based on the manuals of the Brazilian Ministry of Health. ${ }^{11}$ Aspects related to sociodemographics, theoretical knowledge regarding the topic, and attitudes toward the disease were included as well as questions regarding the practical instruction during the course. The questionnaire was pretested, and the necessary adjustments were made. The students were approached without prior notice and were given a brief explanation about the study and its objectives. After agreeing and providing signed informed consent, the students gave anonymous, individual, immediate answers without consulting books or other material. The study was approved by the UFMG Human Research Ethics Committee ( $\mathrm{n}^{-0}$ 07270012.8.0000.5149).

To evaluate their theoretical knowledge and attitudes toward the disease, the two groups were compared using univariate and multivariate analyses. The following variables were used: knowledge regarding the cause, transmission, signs and symptoms, diagnosis, treatment, cure, mandatory notification, and where patients are assisted; perception about the importance of the doctor being able to diagnose and treat leprosy; attitudes toward the disease, that is, maintaining contact with a friend who has been diagnosed with leprosy and being willing to treat people with this disease. The data were stored in databanks using SPSS software.

The variables were described by their frequency distribution. Groups 1 and 2 were compared through a bivariate analysis using the asymptotic Pearson's chi-square test or the exact Pearson's chi-square test. The variables that were not a normally distributed according to Shapiro Wilk's test were analyzed with the Mann Whitney test.

A multivariate analysis using the logistic regression model was performed. All variables significant at the 0.20 level were entered into a multivariate model, which was adjusted by removing the variable with the highest $p$-value in a stepwise fashion until all the remaining variables were significant at the 0.05 level. The goodness of fit of the final multivariate 
logistic regression model was estimated using the Hosmer \& Lemeshow test.

The answers to the open questions were categorized and grouped, and the frequency distributions are presented.

\section{RESULTS}

Of the 632 students enrolled in the two years studied, 540 (85.4\%) participated in the study, with 260 (84.1\%) in Group 1 and $280(86.6 \%)$ in Group 2.

\begin{tabular}{|c|c|c|c|c|}
\hline \multicolumn{5}{|c|}{$\begin{array}{l}\text { Comparative analysis of theoretical knowledge about } \\
\text { leprosy between groups of freshmen (Group 1) and } \\
\text { interns (Group 2) of the UFMG Medical School in } 2012\end{array}$} \\
\hline Variables & $\begin{array}{c}\text { Group } 1 \\
\text { (freshmen) } \\
n=260\end{array}$ & $\begin{array}{c}\text { Group } 2 \\
\text { (interns) } \\
\mathrm{n}=280\end{array}$ & $\begin{array}{c}\text { Total } \\
\mathrm{n}=540\end{array}$ & $P$ value \\
\hline \multicolumn{5}{|l|}{$\begin{array}{l}\text { Where you did you hear } \\
\text { about leprosy }\end{array}$} \\
\hline Family member & $69(26.5)$ & $67(23.9)$ & $136(25.2)$ & $0.485^{1}$ \\
\hline Medical School & $58(22.3)$ & $248(88.6)$ & $306(56.7)$ & $<0.0001^{1}$ \\
\hline Mass media & $187(71.9)$ & $173(61.8)$ & $360(66.7)$ & $0.013^{1}$ \\
\hline Never heard of leprosy & $1(0.4)$ & $3(1.1)$ & $4(0.7)$ & $0.625^{2}$ \\
\hline Other & $118(45.4)$ & $22(7.9)$ & $140(25.9)$ & $<0.0001^{1}$ \\
\hline $\begin{array}{l}\text { Answered correctly that } \\
\text { transmission is by the } \\
\text { respiratory route }\end{array}$ & $92(36.1)$ & $181(65.6)$ & $273(51.4)$ & $<0.0001^{2}$ \\
\hline $\begin{array}{l}\text { Answered correctly that } \\
\text { the signs and symptoms } \\
\text { are areas or skin lesions } \\
\text { with sensory loss }\end{array}$ & $234(90.3)$ & $278(99.3)$ & $512(95.0)$ & $<0.0001^{2}$ \\
\hline $\begin{array}{c}\text { Answered correctly that } \\
\text { diagnosis is essentially } \\
\text { clinical }\end{array}$ & $104(4.2)$ & 198 (71.7) & $302(56.4)$ & $<0.0001^{1}$ \\
\hline $\begin{array}{l}\text { Answered correctly that } \\
\text { treatment is achieved with } \\
\text { antimicrobial drugs }\end{array}$ & $153(59.1)$ & $253(91.0)$ & $406(75.6)$ & $<0.0001^{1}$ \\
\hline $\begin{array}{l}\text { Answered correctly that } \\
\text { leprosy can be cured }\end{array}$ & $205(78.8)$ & $247(88.8)$ & $452(84.0)$ & $<0,006^{1}$ \\
\hline $\begin{array}{l}\text { Answered correctly } \\
\text { that the disease is of } \\
\text { mandatory notification }\end{array}$ & $54(21.0)$ & $252(90.0)$ & $306(57.0)$ & $<0,0001^{1}$ \\
\hline $\begin{array}{l}\text { Answered correctly that } \\
\text { patients are assisted in } \\
\text { Basic Health Units }\end{array}$ & $82(31.9)$ & $154(55.6)$ & $236(44.2)$ & $<0,0001^{1}$ \\
\hline
\end{tabular}

1 Asymptotic Pearson's Chi-square test; 2 Exact Pearson's Chi-square test; ${ }^{*} \leq-1.96 ; * *+1.96$

The analysis of the association between the variable "Group" and sociodemographic variables showed a difference in age, with the students of the last year being older than those of the first year $(\mathrm{p}<0.0001)$. Regarding origin, the students in Group 2 were predominantly from Belo Horizonte, whereas those in Group 1 were predominantly from other Brazilian states $(p<0.0001)$. No difference was found between the two groups regarding gender and income.

\section{TABLE 2}

Comparison of students' attitudes toward leprosy between the groups studied. UFMG, 2012

$\begin{array}{ccccc}\text { Variables } & \begin{array}{c}\text { Group 1 } \\ \mathbf{n = 2 6 0}\end{array} & \begin{array}{c}\text { Group 2 } \\ \mathbf{n = 2 8 0}\end{array} & \text { Total } \mathbf{n = 5 4 0} \text { P Value } \\ \text { Associated Hansen's disease with leprosy } \mathbf{n}(\mathbf{\%}) & & \\ \text { Yes } & 217(83.8) & 247(88.5) & 464(86.2) & 0.110^{1} \\ \text { No } & 42(16.2) & 32(11.5) & 74(13.8) & \end{array}$

How do you think a person with leprosy is treated by others $\mathbf{n}(\%)$

$\begin{array}{ccccc}\begin{array}{c}\text { Normally } \\ \text { Usually avoiding physical } \\ \text { contact }\end{array} & 73(2.7)^{*} & 34(12.2)^{* *} & 41(7.6) & \\ \begin{array}{c}\text { People withdraw because it } \\ \text { is a contagious disease }\end{array} & 14(5.4) & 20(7.2) & 34(6.3) & 0.001^{1} \\ \begin{array}{c}\text { People withdraw because it } \\ \text { is a prejudiced disease }\end{array} & 189(73.3) & 187(67.0) & 376(70.0) & \\ \quad \text { Don't know } & 5(1.9) & 6(2.2) & 11(2.0)\end{array}$

If you were diagnosed with leprosy $n(\%)$

I would have no problem $52(20.0)^{*} \quad 94(33.9)^{* *} \quad 146(27.2)$ telling other people

I would tell family members

or people who are close $197(75.8)^{* *} \quad 166(59.9)^{*} \quad 363(67.6)$ to me

$<0.0001^{2}$

I would hide it as much as

I could, even from family members

$7(2.7) \quad 14(5.1) \quad 21(3.9)$

Other

4 (1.5)

3 (1.1)

$7(1.3)$

If your best friend told you he or she had been diagnosed with leprosy, you would n (\%)

Interact to them in the same

$$
\text { way as before }
$$

$129(49.6) \quad 221(78.9) \quad 350(64.8)$

Avoid some situations of

physical contact, closed

spaces and using the same utensils

Withdraw from him/her $\quad 0(0.0) \quad 0(0.0) \quad 0(0.0)$

After you graduate, would you be willing to assist leprosy patients n (\%)?

$\begin{array}{ccccc}\text { Yes } & 258(99.2) & 247(91.8) & 505(95.5) & <0.0001^{1} \\ \text { No } & 2(0.8) & 22(8.2) & 24(4.5) & \end{array}$

1 Asymptotic Pearson's Chi-square test; 2 Exact Pearson's Chi-square test: ${ }^{*} \leq-1.96 ;{ }^{* *} \geq+1.96$

A medical student enters the course with some knowledge about leprosy obtained from different sources, especially from mass media and primary and secondary education grouped together in the variable "Other" in Table 1. For Group 2, the Medical School was the main source of information, and this group had greater theoretical knowledge compared to Group 1 , as shown by all the variables analyzed (Table 1 ). Both groups associated Hansen's disease with leprosy. However, more favorable attitudes toward the disease were shown by the group of interns when compared to the group of freshmen (Table 2).

Table 3 presents the final model of the multivariate analysis for the variables regarding knowledge about and attitudes toward leprosy. The medical interns had a 29 times greater chance of having learned about leprosy at the Medical School, as well as a 40 times greater chance of knowing it is a disease 


\begin{tabular}{|c|c|c|c|c|c|}
\hline \multicolumn{6}{|c|}{$\begin{array}{ll}\text { TABLE } 3\end{array}$} \\
\hline Variables & Group 1 & Group 2 & OR & CI $95 \%$ & P Value \\
\hline \multicolumn{6}{|l|}{ Heard about leprosy in Medical School } \\
\hline Yes & $58(22.3)$ & $248(88.6)$ & 28.93 & $13.62 ; 1.44$ & $<0.0001$ \\
\hline No & $202(77.7)$ & $32(11.4)$ & 1 & & \\
\hline \multicolumn{6}{|l|}{ In relation to diagnosis } \\
\hline Answered correctly & $104(40.2)$ & 198 (71.7) & 2.83 & $1.41 ; 5.71$ & 0.004 \\
\hline Answered incorrectly or doesn't know & $155(59.8)$ & $78(28.3)$ & 1 & & \\
\hline \multicolumn{6}{|l|}{ How is the treatment performed? } \\
\hline Answered correctly & $153(59.1)$ & $243(91.0)$ & 4.19 & $1.84 ; 9.55$ & 0.001 \\
\hline Answered incorrectly or doesn't know & $106(40.9)$ & $25(9.0)$ & 1 & & \\
\hline \multicolumn{6}{|c|}{ Is leprosy a disease of mandatory notification? } \\
\hline Answered correctly & $54(21.0)$ & $252(90.0)$ & 39.88 & $18.17 ; 87.55$ & $<0.0001$ \\
\hline Answered incorrectly or doesn't know & $203(79.0)$ & $28(10.0)$ & 1 & & \\
\hline \multicolumn{6}{|c|}{ If your best friend were diagnosed with leprosy, you would } \\
\hline Maintain contact & $129(49.6)$ & $221(78.9)$ & 4.72 & $2.31 ; 9.63$ & $<0.0001$ \\
\hline Withdraw & $131(50.4)$ & $59(21.1)$ & 1 & & \\
\hline
\end{tabular}

$P$ Value $=0.520$ in the Hosmer-Lemeshow Test

of mandatory notification. It is also important to note the greater predisposition of the interns to maintaining contact with a friend who was diagnosed with leprosy.

A total of $81 \%$ of the interns stated that leprosy had been addressed during the Medicine course. The discipline Semiology (Dermatology Module) was highlighted as the most relevant in the theoretical approach $(78.8 \%)$, followed by Internal Medicine and Microbiology (both 6.8\%), Infectious Diseases (3.6\%) and "other" disciplines, at $4.1 \%$.
However, only $28.7 \%$ of the students observed a leprosy patient being attended by a doctor or attended one themselves. Most of these practical activities ( $81 \%$ ) occurred in the Dermatology ambulatory (where there is a referral center for leprosy); $10.9 \%$ were in Internal Medicine outpatient clinics, at the teaching hospital or at the basic health units, with $8.1 \%$ during the Collective Health Internship.

The interns who felt more prepared to answer the basic questions of patients and contacts were those who had studied

TABLE 4

Perception of UFMG 2012 Medical School interns regarding their ability to diagnose, treat and answer basic questions about leprosy, according to the existence or not of theoretical teaching about the topic

\begin{tabular}{|c|c|c|c|c|c|}
\hline \multirow{2}{*}{ Variables } & \multicolumn{3}{|c|}{ Did the student study any theoretical discipline about leprosy? } & \multirow{2}{*}{ Total } & \multirow{2}{*}{ P Value } \\
\hline & Yes & No & Doesn't remember & & \\
\hline \multicolumn{6}{|c|}{ Do you feel prepared to diagnose leprosy? } \\
\hline Yes & $87(39.4)$ & $10(30.3)$ & $3(15.8)$ & $100(36.6)$ & \multirow{3}{*}{$0.089^{1}$} \\
\hline No & $134(60.6)$ & $23(69.7)$ & $16(84.2)$ & $173(63.4)$ & \\
\hline Total & 221 & 33 & 19 & 273 & \\
\hline \multicolumn{6}{|c|}{ Do you feel prepared to treat leprosy? } \\
\hline Yes & $45(20.4)$ & $6(18.2)$ & $1(5.3)$ & 52 & \multirow{3}{*}{$0.272^{1}$} \\
\hline No & $176(79.6)$ & $27(81.8)$ & $18(94.7)$ & 221 & \\
\hline Total & 221 & 33 & 19 & 273 & \\
\hline \multicolumn{6}{|c|}{ Do you feel prepared to answer basic questions about leprosy? } \\
\hline Yes & $123(55.9)^{* *}$ & $11(33.3)^{*}$ & $5(26.3)$ & 139 & \multirow{3}{*}{$0.004^{1}$} \\
\hline No & $97(44.1)^{*}$ & $22(66.7)^{* *}$ & $14(73.7)$ & 133 & \\
\hline Total & 220 & 33 & 19 & 272 & \\
\hline
\end{tabular}

1 Asymptotic Pearson's Chi-square test; 2 Exact Pearson's Chi-square test;

* standardized adjusted residual $<-1.96$;

** standardized adjusted residual $>1.96$. 
a discipline in which leprosy was addressed (Table 4). Those who observed a leprosy patient being attended by a doctor or attended one themselves felt more prepared to diagnose and treat the disease, in addition to answering basic questions (Table 5).

\section{TABle 5}

Perception of UFMG 2012 Medical School interns regarding their ability to diagnose, treat and answer

basic questions about leprosy, according to the existence or not of practical instruction about the topic

\begin{tabular}{|c|c|c|c|c|c|}
\hline \multirow{2}{*}{ Variables } & \multicolumn{3}{|c|}{$\begin{array}{l}\text { Did the student participate in any } \\
\text { practical activity regarding leprosy? }\end{array}$} & \multirow{2}{*}{ Total } & \multirow{2}{*}{ P Value } \\
\hline & Yes & No & $\begin{array}{l}\text { Does not } \\
\text { remember }\end{array}$ & & \\
\hline \multicolumn{6}{|c|}{ Do you feel prepared to diagnose leprosy? } \\
\hline Yes & $39(49.4)^{* *}$ & $57(30.3)^{*}$ & $4(50.0)$ & $100(36.4)$ & \multirow{3}{*}{$0.009^{1}$} \\
\hline No & $40(50.6)^{*}$ & $131(69.7)^{* *}$ & $4(50.0)$ & 175 (63.6) & \\
\hline Total & 79 & 188 & 8 & 275 & \\
\hline \multicolumn{6}{|c|}{ Do you feel prepared to treat leprosy? } \\
\hline Yes & $27(34.2)^{* *}$ & $24(12.8)^{*}$ & $1(12.5)$ & $52(18.9)$ & \multirow{3}{*}{$<0.0001^{1}$} \\
\hline No & $52(65.8)^{*}$ & $164(87.2)^{* *}$ & 7 (87.5) & $223(81.1)$ & \\
\hline Total & 79 & 188 & 8 & 275 & \\
\hline \multicolumn{6}{|c|}{ Do you feel prepared to answer basic questions about leprosy? } \\
\hline Yes & $59(75.6)^{* *}$ & $78(41.5)^{*}$ & $3(37.5)$ & $140(51.1)$ & \multirow{3}{*}{$<0.0001^{2}$} \\
\hline No & $19(24.4)^{*}$ & $110(58.5)^{* *}$ & $5(62.5)$ & $134(48.9)$ & \\
\hline Total & 78 & 188 & 8 & 274 & \\
\hline
\end{tabular}

1 Asymptotic Pearson's Chi-square test; 2 Exact Pearson's Chi-square test;

*standardized adjusted residual $<-1.96$;

** standardized adjusted residual $>1.96$.

The reasons the interns gave for not feeling prepared to diagnose and treat leprosy patients were related to insufficient knowledge received at the Medical School, which was reported as a lack of theoretical knowledge $(36.8 \%)$, a lack of theoretical and practical knowledge (40.2\%) and a lack of practical experience $(23.0 \%)$.

\section{DISCUSSION}

Most of the students entered the Faculty of Medicine with knowledge about the signs and symptoms of leprosy, mainly due to formal basic education and mass media. These findings are corroborated by the literature, which shows that health and education are efficient allies. ${ }^{12,13}$ Educational campaigns may be a good strategy to reach the population at large, quickly disseminating easily assimilated information. ${ }^{14}$ Informative and educational activities directed at school-aged children and their teachers increase knowledge and optimize health education strategies aimed at early case detection and stigma reduction. ${ }^{15,16}$ Thus, mass education campaigns and in- formation about leprosy in primary and secondary education should be maintained and continuously encouraged.

The interns showed considerably higher chances of having heard about leprosy at the Medical School when compared to the freshmen; they received basic information about the topic, especially related to the diagnosis, treatment and epidemiological situation. If this situation from a statistical point of view could seem very favorable, one cannot say the same when assessed from the perspective of education and public health, since large portions of the final-year medical students do not have basic information about the disease - for example, transmission (34.4\%); the clinical nature of diagnosis (29.9\%); existence of cure (11.2\%) and patient care in primary health care $(44.4 \%)$ - contrary to what would be expected for a disease defined as a public health problem and mandatory reporting. With regard to this last point, in particular, it is troubling to learn that $10 \%$ of the students at the end of their training did not possess this information.

The implementation of the Unified Health System in Brazil and its main directives, especially universalization of access and priority given to primary health care, have enabled the decentralization of assistance to people with leprosy. With the publication of the Health Assistance Operational Norm (NOAS/SUS 01/2001), the commitment of municipalities with integral health assistance has been regulated and expanded, and leprosy care has been defined as a strategic area. ${ }^{17}$ However, only $55.6 \%$ of the students knew that patients should be treated in basic health units.

Despite the knowledge acquired during the Medicine course, incorrect concepts regarding transmission, aspects of diagnosis and even cure of the disease remained in a significant percentage of the students at the end of the course, indicating that the topic was insufficiently addressed. This reality made the students apprehensive about assisting patients and family members. A study with Indian medical students showed similar deficiencies in knowledge, ${ }^{18}$ and similar findings with other students from the health area in and outside Brazil have been reported. ${ }^{19-21}$

Dermatology was a discipline that was important for theoretical and practical learning about leprosy; in contrast, the other disciplines showed limited input in addressing the topic. Although the participation of dermatologists in continuing education is highligted, ${ }^{22,23}$ Opromolla, as early as 1988, emphasized the fact that leprosy is a disease with primary skin manifestations but of a systemic nature and a broad spectrum of clinical manifestations, which justifies it being taught in various modules of a medical course. ${ }^{24}$ The high percentage of students who were unaware of the clinical aspects, epidemiology and strategies for treatment in primary health care shows that it 
is important for the topic to be addressed in disciplines of the basic cycle as well as in those of the clinical cycle. It should be noted that the topic should also be addressed in public health disciplines, as it is a disease of mandatory notification, which requires integral assistance in primary health care. ${ }^{17,25}$

The present trend for medical curricula to be guided by the prevalent nosology, with an emphasis on primary health care, is desirable. However, this could have a negative impact on leprosy instruction in low-prevalence areas due to the lack of patients, among other factors. ${ }^{26}$ In locations such as that described in the present study, the possibility of contact with leprosy patients is greater in referral centers, where complicated cases predominate. This situation is not ideal for undergraduate instruction, but patients are referred to these centers by primary care doctors, and the difficulties in confirming the diagnosis represents a good learning experience. Additionally, referral centers have multidisciplinary teams, providing the student with an overview of how to approach various aspects of the disease, such as contact examination, treatment of the infection and reactions, and prevention of disabilities and rehabilitation, in addition to the need to approach the social aspects. At the medical school where the study was conducted, there is a state referral center for leprosy linked to the Dermatology Service. However, not all of the students participate in activities at this center. Thus, the practical instruction was insufficient during the course and did not include many of the students. Indeed, those who had an opportunity to participate in activities at the center were more confident in their capacity to attend a leprosy patient.

Regarding leprosy, primary health care must, more than ever, be articulated to other levels of the health system and must have the role of coordinating all efforts related to patient assistance and training of professionals. ${ }^{27,28}$ Only with such integrated functioning will it be possible to overcome the dilemma of leprosy instruction, not allowing it to displace more prevalent diseases but also not ignoring it, which could result in increased leprosy prevalence.

Another aspect studied was the students' attitudes toward leprosy. Although the name leprosy was changed to Hansen's Disease in Brazil, most of the students, including the freshmen, associated the two terms..$^{29}$ In practice, the term "leprosy" still makes it difficult for those affected and for the community in general to address the disease, as it is associated with physical deformities. ${ }^{30}$

The knowledge acquired by the group of interns had a positive influence on decreasing such prejudiced attitudes. Informative activities, according to Feenstra, lead to increases in knowledge, changes in behavior and reduced stigma. ${ }^{12}$
Although most of the students (95.5\%) reported being willing to attend leprosy patients after graduating, the percentage of those who would not do so increased at the end of the course. A lack of practical experience with complex diseases and choosing a medical specialty, with a lack of interest in anything that is not related to it, could determine this. However, less positive attitudes toward certain groups of patients and diseases during the Medicine course have been described and, in this case, could reflect a negative attitude toward the disease. $^{31}$

Contemplation about leprosy instruction and its inclusion in the curricula of medical schools should be a continuous and mandatory exercise. Because leprosy is an important disease for public health, all doctors should graduate with basic knowledge about it. The present study pointed up students deficiency about this topic. Self-evaluation and the evaluation of services at health care facilities are essential for the identification of gaps in theoretical and practical knowledge and should guide continuing education with a joint commitment of medical schools and the health system.

\section{REFERENCES}

1. Lanza FM, Lana FCF. O processo de trabalho em hanseníase: tecnologias e atuação da equipe de saúde da família. Texto Contexto Enferm 2011; 20: 238-246.

2. Penna MLF, Oliveira MLW, Carmo EH, Penna GO, Temporão JG. The influence of increased access to basic healthcare on the trends in Hansen's disease detection rate in Brazil from 1980 to 2006. Rev Soc Bras Med Trop 2008; 41: 6-10.

3. Barreto ML, Teixeira MG, Bastos FI, Ximenes RA, Barata $\mathrm{RB}$, Rodrigues LCl. Successes and failures in the control of infectious diseases in Brazil: social and environmental context, policies, interventions, and research needs. Lancet 2011; 377: 1877-1889.

4. Lana FCF, Davi RFL, Lanza FM, Amaral EP. Detecção da hanseníase e índice de desenvolvimento humano dos municípios de Minas Gerais, Brasil. Rev Eletrônica Enferm 2009; 11: 539-544.

5. Ignotti E, Paula RC. Saúde Brasil 2010: Uma análise da situação de saúde e de evidências selecionadas de impacto de ações de vigilância em saúde. Situação epidemiológica da hanseníase no Brasil: análise de indicadores selecionados 2001-2010. [cited 30/01/2013] Available at http:/ / portal.saude.gov.br/portal/arquivos/pdf/cap_9_saude_brasil_2010.pdf.

6. Saunderson P. Learning to manage leprosy after 2005: preserving critical knowledge and exploiting new technology. Lepr Rev 2005; 76: 2-4. 
7. Penna ML, Temporão JG, Grossi MA, Penna GO. Leprosy control: knowledge shall not be neglected. J Epidemiol Community Health 2011; 65: 473-474.

8. Ebenso J. An overview of training and development needs. Lepr Rev 2012; 83: 127-128.

9. World Health Organization (WHO). Weekly epidemiological record Relevé épidémiologique hebdomadaire. Global leprosy situation, 2012. Week Epidemiol Rec 2012; 87: 317-328.

10. Alves CRP, Ribeiro MMF, Melo EM, Araújo MG. Ensino da hansenologia: desafios atuais. An Bras Dermatol 2014; 89: 454-459.

11. Brasil. Ministério da Saúde. Secretaria de Políticas de S. Guia para o controle da hanseníase. Leprosy control guide. Série A Normas e Manuais Técnicos,111. 2002; 89p.

12. Feenstra P. "Elimination" of leprosy and the need to sustain leprosy services, expectations, predictions and reality. Inter J Lepr 2003; 71: 248-256.

13. Bagade PL, Baliram B. Community participation in case detection of leprosy in Nagpur district of Maharashtra. Indian J Lepr 1999; 7: 465-469.

14. Brasil intensifica ações para eliminação da hanseníase. Available from: http://portalsaude.saude.gov.br/ portalsaude/noticia /9086/ 162/brasil- reforca-acoes-para-eliminacao-da-hanseniase.html.

15. Oliveira SS, Guerreiro LB, Bonfim PM. Educação para a saúde: a doença Como conteúdo nas aulas de ciências. Hist Cienc Saude Manguinhos 2007; 14: 1313-1328.

16. Rajaratnam J, Abel R, Arumai M. Is knowledge of leprosy adequate among teachers? A comparative study. Lepr Rev 1999; 70: 28-33.

17. Brasil. Ministério da Saúde. Portaria n.95 de 26 de janeiro de 2001. Norma Operacional da Assistência Saúde NOAS/ SUS 01/2001. Ministério da Saúde, Brasília (DF), 2001.

18. Giri PA, Phalke DB, Aarif SMM. A study of knowledge, attitude and practices regarding leprosy among undergraduates and interns of a medical college and hospital from rural India. Indian J Lepr 2011; 83: 75-80.

19. Dias A, Cyrino EG, Lastória JC. Conhecimentos e necessidades de aprendizagem de estudantes de fisioterapia sobre a hanseníase. Hansen Int 2007; 32: 9-18.

20. Silva MN, Nardi SMT, Abe PB. Terapia Ocupacional e hanseníase: ampliando conhecimentos. Cadernos de Terapia Ocupacional da UFSCar. In: XII Congresso Brasileiro de Terapia Ocupacional e IX Congresso Latino Americano de Terapia Ocupacional, 2011, São Paulo.

21. Kawuma HJS, Nabukenya-Mudiope MG. A study on inclusion of leprosy in the curricula of pre-service health training institutions in Uganda. Lepr Rev 2011; 82: 296-303.
22. Smith WCS, ILEP. A research strategy to develop new tools to prevent leprosy, improve patient care and reduce the consequences of leprosy. Five year leprosy research strategy approved by ILEP Board October 2011. Lepr Rev 2012; 83: 6-15.

23. Faye O, Hay RJ, Ryan TJ, Keita S, Traoré AK, Mahé A. A public health approach for leprosy detection based on a very short term-training of primary health care workers in basic dermatology. Lepr Rev 2007; 78: 11-16.

24. Opromolla DVA. O ensino da hansenologia nas faculdades. Hansen Int 1988; 13: 27-33.

25. Brasil. Ministério da Saúde. Portaria № 3.125 de 07 de outubro de 2010. Brasília (DF): Ministério da Saúde, 2010. [cited 12/01/2013]; Available from: http:/ /bvsms.saude.gov. br/bvs/saudelegis/gm/2010/prt3125_07_10_2010.html.

26. Brasil. Ministério da Educação. Parecer CNE/CES no 1.133/2001, aprovado em 7 de agosto de 2001. Diretrizes curriculares nacionais dos cursos de graduação em enfermagem, medicina e nutrição. [Legislação na internet]. Brasília, 2001. [cited 12/01/2013]; Available from: http:/ / portal.mec.gov.br/sesu/arquivos/pdf /113301 EnfMedNutr.pdf.

27. Kringos DS, Boerma WGW, Hutchinson A, van der Zee J, Groenewegen PP. The breadth of primary care: a systematic literature review of its core dimensions. BMC Health Serv Res 2010; 10: 65.

28. Starfield B. Atenção primária. Equilíbrio entre necessidades de saúde, serviços e tecnologia. Organização das Nações Unidas para a Educação, a Ciência e a Cultura, Brasília, 2002.

29. Brasil. Ministério da Saúde. Portaria $n^{\circ} 165$, de 14 de maio de 1976. Instruções para execução das normas de controle da hanseníase, que estabelece a política de controle da hanseníase. Brasília, 1977.

30. Silva MC, Paz EPA. Educação em saúde no programa de controle da hanseníase: a vivência da equipe multiprofissional. Rev Enferm 2010; 14: 223-229.

31. Griffith $\mathrm{CH}$, Wilson JF. The loss of student idealism in the 3rd-year clinical clerkships. Eval Health Prof 2001; 24: 61-71.

\section{CONTRIBUTIONS}

CRPA contributed substantially to the conception, design, data acquisition, analysis, data interpretation, and drafting of the article, participated jointly with the other authors in the critical revision of the intellectual content, and approved the final version for publication. MGA, MMFR and EMM contributed substantially to the conception, design, analysis, data 
interpretation, and drafting of the article, participated in the critical revision of the intellectual content, and approved the final version for publication

\section{CONFLICTS OF INTEREST}

All authors declare that the answer to the question on competing interest form are all ' $\mathrm{No}^{\prime}$, and therefore have nothing to declare.

\section{POSTAL ADDRESS}

Av. Professor Alfredo Balena, 190 - sala 246

CEP 30130-100 - Belo Horizonte - MG

E-mail:cynthiarpalves@yahoo.com.br 